\title{
Reactivity of M" Metal-Substituted Derivatives of Pig Purple Acid Phosphatase (Uteroferrin) with Phosphate
}

\author{
Mark B. Twitchett, ${ }^{\dagger}$ Gerhard Schenk, ${ }^{\dagger, \ddagger}$ Manuel A. S. Aquino, ${ }^{\dagger}$ Douglas T.-Y. Yiu, ${ }^{\S}$ Tai-Chu Lau,,${ }^{\S}$ and \\ A. Geoffrey Sykes*, \\ Department of Chemistry, University of Newcastle, Newcastle upon Tyne NE1 7RU, U.K., \\ Department of Biochemistry, University of Queensland, Brisbane 4072, Australia, and Department \\ of Biology \& Chemistry, City University of Hong Kong, Tat Chee Avenue, Hong Kong \\ Received January 14, 2002
}

The Fe ${ }^{\| \prime}$ of the binuclear Fe" $\mathrm{Fe}^{\mathrm{III}}$ active site of pig purple acid phosphatase (uteroferrin) has been replaced in turn by five $\mathrm{M}^{\prime \prime}$ ions ( $\mathrm{Mn}^{\prime \prime}, \mathrm{Co}^{\prime \prime}, \mathrm{Ni}^{\prime \prime}, \mathrm{Cu}^{\prime \prime}$, and $\left.\mathrm{Zn}^{\prime \prime}\right)$. An uptake of 1 equiv of $\mathrm{M}^{\prime \prime}$ is observed in all cases except that of $\mathrm{Cu}^{\prime \prime}$, when a second more loosely bound $\mathrm{Cu}^{\prime \prime}$ is removed by treatment with edta. The products have been characterized by different analytical procedures and by UV-vis spectrophotometry. At $25^{\circ} \mathrm{C}, I=0.100 \mathrm{M}(\mathrm{NaCl})$, the nonenzymatic reactions with $\mathrm{H}_{2} \mathrm{PO}_{4}^{-}$give the $\mu$-phosphato product, and formation constants $K / \mathrm{M}^{-1}$ show an 8-fold spread at pH 4.9 of $740(\mathrm{Mn}), 165(\mathrm{Fe}), 190(\mathrm{Co}), 90(\mathrm{Ni}), 800(\mathrm{Cu}), 380(\mathrm{Zn})$. The variations in $K$ correlate well with stability constants for the complexing of $\mathrm{H}_{2} \mathrm{PO}_{4}{ }^{-}$and $\left(\mathrm{CH}_{3} \mathrm{O}\right) \mathrm{HPO}_{3}{ }^{-}$with $\mathrm{M}^{\prime \prime}$ hexaaqua ions. At $\mathrm{pH} 4.9$ with $\left[\mathrm{H}_{2} \mathrm{PO}_{4}^{-}\right] \geq 3.5 \mathrm{mM}$ rate constants $k_{\text {obs }}$ decrease, and an inhibition process in which a second $\left[\mathrm{H}_{2} \mathrm{PO}_{4}{ }^{-}\right]$ coordinates to the dinuclear center is proposed. The mechanism considered accounts for most but not all of the features displayed. Thus $K_{1}$ values for the coordination of phosphate to $\mathrm{M}^{\| \prime}$ are in the range10-60 $\mathrm{M}^{-1}$, whereas $K_{2}$ values for the bridging of the phosphate to Fe ${ }^{I I I}$ are in the narrower range 7.8-12.4. From the fits described $K_{\mathrm{i}}$ $\sim 10^{3} \mathrm{M}^{-1}$ for the inhibition step, which is independent of the identity of $\mathrm{M}^{\prime \prime}$. Values of $k_{\mathrm{obs}}$ decrease with increasing $\mathrm{pH}$, giving $\mathrm{pK}_{\mathrm{a}}$ values which are close to 3.8 and independent of $\mathrm{M}^{\prime \prime}\left(\mathrm{Fe}^{\prime \prime}, \mathrm{Zn}^{\prime \prime}, \mathrm{Mn}^{\prime \prime}\right)$. The acid dissociation process is assigned to $\mathrm{Fe}^{\mathrm{III}}-\mathrm{OH}_{2}$ to $\mathrm{Fe}^{\mathrm{III}}-\mathrm{OH}^{-}$, where $\mathrm{OH}^{-}$is less readily displaced by phosphate.

\section{Introduction}

Purple acid phosphatases (PAPs) are non-heme iron containing enzymes which have been isolated from mammals, plants, and fungal sources. ${ }^{1-4}$ One of the most widely studied is uteroferrin (Uf) isolated from pig uteri $\left(M_{\mathrm{r}}=35\right.$ $\mathrm{kDa} ; 318$ amino acids). ${ }^{5}$ The active form of the enzyme has a binuclear $\mathrm{Fe}^{\mathrm{II}} \mathrm{Fe}^{\mathrm{III}}$ center, which catalyzes the hydrolysis of phosphate esters (eq 1). ${ }^{1-4}$ Plant PAPs have also been

$$
(\mathrm{RO}) \mathrm{PO}_{3}{ }^{2-}+\mathrm{H}_{2} \mathrm{O} \rightarrow \mathrm{HPO}_{4}{ }^{2-}+\mathrm{ROH}
$$

studied, e.g., kidney bean (kbPAP), which has a binuclear

\footnotetext{
* Author to whom correspondence should be addressed. E-mail: a.g.sykes@newcastle.ac.uk.

$\dagger$ University of Newcastle.

$\doteqdot$ University of Queensland.

$\S$ City University of Hong Kong.

(1) Twitchett, M. B.; Sykes, A. G. Eur. J. Inorg. Chem. 1999, 21052115.

(2) Sträter, N.; Lipscomb, W. N.; Klabunde, T.; Krebs, B. Angew. Chem., Int. Ed. Engl. 1996, 35, 2024-2055.

(3) Klabunde, T.; Krebs, B. Struct. Bonding 1997, 89, 177-198. (b) Schenk, G.; Guddat, L. W.; Ge, Y.; Carrington, L. E.; Hume, D. A.; Hamilton, S.; de Jersey, J. Gene 2000, 250, 117. (c) Schenk, G.; Korsinczky, M. L. J.; Hume, D. A.; Hamilton, S.; de Jersey, J. Gene 2000, 255, 419 .
}

10.1021/ic020037f CCC: $\$ 22.00 \quad$ C 2002 American Chemical Society Published on Web 10/10/2002
$\mathrm{Zn}^{\mathrm{II}} \mathrm{Fe}^{\mathrm{III}}$ center, ${ }^{4,6,7}$ and in recent papers the $\mathrm{Mn}^{\mathrm{II}} \mathrm{Fe}^{\mathrm{III}}$ (sweet potato ${ }^{8}$ ) and $\mathrm{Zn}^{\mathrm{II}} \mathrm{Fe}^{\mathrm{III}}$ (sweet potato and soybean ${ }^{8,9}$ ) active sites have been reported. Different chemically substituted $\mathrm{M}^{\mathrm{II}} \mathrm{Fe}^{\mathrm{III}}$ sites have been reported with $\mathrm{M}^{\mathrm{II}}=\mathrm{Co}^{\mathrm{II}}, \mathrm{Cu}^{\mathrm{II}}, \mathrm{Cd}^{\mathrm{II}}$, $\mathrm{Hg}^{\mathrm{II}}{ }^{10-12}$

X-ray crystal structures of the $111 \mathrm{kDa}$ homodimeric (disulfide-bridged) $\mathrm{Zn}^{\mathrm{II}} \mathrm{Fe}^{\mathrm{III}} \mathrm{kbPAP}$ enzyme (resolution 2.65 $\AA)$, the same protein with $\mu$-phosphate coordinated $(2.7 \AA)$, and the product with $\mu$-tungstate(VI) inhibitor coordinated (3.0 ̊) have been reported. ${ }^{7}$ More recently the structures of

(4) Sträter, N.; Klabunde, T.; Tucker, P.; Witzel, H.; Krebs, B. Science $1995,1489$.

(5) Chen, T. T.; Bazer, F. W.; Cetorelli, J. J.; Pollard, W. E.; Roberts, R. M. J. Biol. Chem. 1973, 248, 8560. (b) Baumbach, G. A.; Ketcham, C. M.; Richardson, D. A.; Bazer, F. W.; Roberts, R. M. J. Biol. Chem. 1986, 261, 12869.

(6) Beck, J. L.; de Jersey, J.; Zerner, B.; Hendrich, M. P.; Debrunner, P. J. Am. Chem. Soc. 1988, 110, 3317.

(7) Klabunde, T.; Sträter, N.; Fröhlich, R.; Witzel, H.; Krebs, B. J. Mol. Biol. 1996, 259, 737.

(8) Schenk, G.; Ge, Y.; Carrington, L. E.; Wynne, C. J.; Searle, I. R.; Carroll, B. J.; Hamilton, S.; de Jersey, J. Arch. Biochiem. Biophys. 1999, 370, 183. (b) Schenk, G.; Boutchard, C. L.; Carrington, L. E.; Noble, C. J.; Moubaraki, B.; Murray, K. S.; de Jersey, J.; Hanson, G. R.; Hamilton, S. J. Biol. Chem. 2001, 276, 19084.

(9) Durmus, A.; Eicken, C.; Sift, B. H.; Kratel, A.; Kappl, R.; Hüttermann, J.; Krebs, B. Eur. J. Biochem. 1999, 260, 709.

Inorganic Chemistry, Vol. 41, No. 22, 20025787 
Twitchett et al.

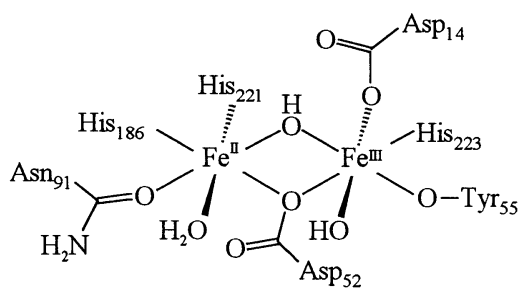

Figure 1. Structure of $\mathrm{Fe}^{\mathrm{II}} \mathrm{Fe}^{\mathrm{III}}$ active site of pig (uteroferrin) purple acid phosphatase.

$\mu$-phosphato derivatives of mammalian PAPs (38 kDa) from Uf $(1.55 \AA)^{13}$ and rat $(2.7 \AA),{ }^{14}$ in the $\mathrm{Fe}^{\mathrm{III}} \mathrm{Fe}^{\mathrm{III}}$ nonactive state, have been determined. The high-resolution Uf structure, Figure $1,{ }^{13}$ confirms octahedral coordination at both metals. From sequence homologies and spectroscopic studies there are similarities with kbPAP, and the dimetallic ligation appears to be identical for PAPs from different sources. Thus the two metals are bridged by a $\mu$-hydroxo group and a single $\mathrm{O}$ atom of aspartate, and the $\alpha$-carbon atoms of the seven coordinated amino acids superimpose. The bridging hydroxide and other structural features are supported by physical measurements..$^{15-17}$

In addition three histidines (His-202, -295, and -296) are located near to the dimetallic center of kbPAP and are in positions where they can interact with free phosphate. ${ }^{7}$ The corresponding residues in the mammalian PAPs are His-92, Glu-194, and His-195. In the mammalian structures it has been observed that His-92 and His-195 hydrogen bond to the bridging phosphate, ${ }^{13,14}$ but no similar role is envisaged for Glu-194. The conservation of two of the histidines, Figure 2 , and ability to superimpose the different structures suggest a mechanistic relevance.

In previous work on $\mathrm{Fe}^{\mathrm{II}} \mathrm{Fe}^{\mathrm{III}} \mathrm{Uf},{ }^{18}$ the reactions of different phosphates (referred to collectively as $\mathrm{PO}_{4}$ ) have been studied, and the mechanism depicted in eqs 2 and 3 has been proposed. The reaction with $\mathrm{H}_{2} \mathrm{PO}_{4}{ }^{-}$can be regarded as a

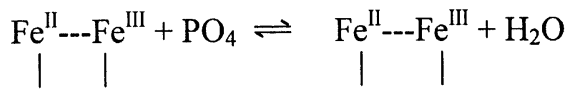

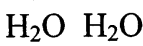

$$
\begin{aligned}
& \begin{array}{lll}
\mathrm{PO}_{4} & \mathrm{H}_{2} \mathrm{O}
\end{array} \\
& \underset{\mathrm{PO}_{4} \mathrm{H}_{2} \mathrm{O}}{\mathrm{Fe}^{\mathrm{II}}---\mathrm{Fe}^{\mathrm{III}}} \rightleftharpoons \underset{\substack{\mathrm{PO}_{4} \\
\mathrm{Fe}^{\mathrm{II}}---\mathrm{Fe}^{\mathrm{III}}+\mathrm{H}_{2} \mathrm{O}}}{\mathrm{PO}_{4}}
\end{aligned}
$$

prototype for ester hydrolysis of (RO) $\mathrm{PO}_{3}{ }^{2-}$. The $\mathrm{pH}$ dependence of reaction 3 has been assigned to acid dissociation of $\mathrm{Fe}^{\mathrm{III}}-\mathrm{OH}_{2}$. To bring about ester hydrolysis the substitution

(10) Beck, J. L.; Keough, D. T.; de Jersey, J.; Zerner, B. Biochim. Biophys. Acta 1984, 791, 357.

(11) Beck, J. L.; McArthur, M. J.; de Jersey, J.; Zerner, B. Inorg. Chim. Acta 1988, 153, 39.

(12) Holz, R. C.; Que, L., Jr. J. Am. Chem. Soc. 1992, 114, 4434.

(13) Guddat, L. W.; McAlpine, A. S.; Hume, D.; Hamilton, S.; de Jersey, J.; Martin, J. L. Structure 1999, 7, 757.

(14) Uppenberg, J.; Lindquist, F.; Svensson, C.; Ek-Rylander, B.; Andersson, G. J. Mol. Biol. 1999, 290, 201. (b) Lindquist, Y.; Johansson, E.; Kaija, H.; Vikho, P.; Schneider, G. J. Mol. Biol. 1999, 291, 135.

(15) Gehring, S.; Fleischhauer, P.; Behlendorf, M.; Huber, M.; Lorösch, J.; Haase, W.; Dietrich, M.; Witzel, H.; Löcke, R.; Krebs, B. Inorg. Chim. Acta 1996, 252, 13.

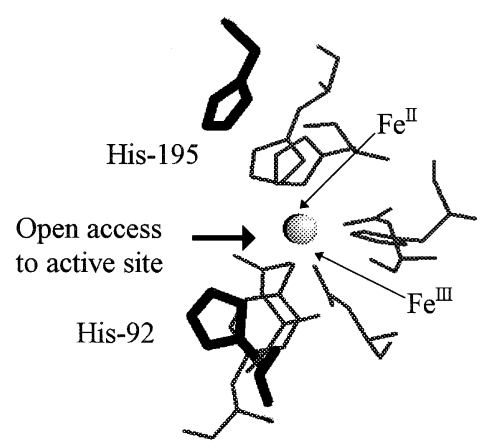

Figure 2. Structure of $\mathrm{Fe}^{\mathrm{II}} \mathrm{Fe}^{\mathrm{III}}$ active site of pig (uteroferrin) purple acid phosphatase showing access to the active site and the proximity of His-92 and His-195.

of the $\mathrm{OH}^{-}$of $\mathrm{Fe}^{\mathrm{III}}-\mathrm{OH}$ into the $\mathrm{P}^{\mathrm{v}}$ coordination sphere with displacement of $\mathrm{RO}^{-}$has been proposed (eq 4). ${ }^{18-20} \mathrm{Ad}-$ ditional features have come to light in the present work.

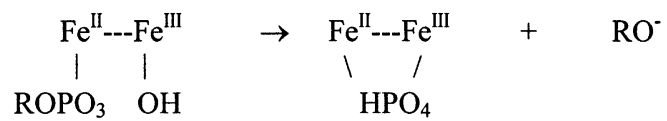

An appraisal of the effect of different $\mathrm{M}^{\mathrm{II}}$ metals is of particular interest in view of the involvement of $\mathrm{Fe}^{\mathrm{II}}, \mathrm{Zn}^{\mathrm{II}}$, and $\mathrm{Mn}^{\mathrm{II}}$ in naturally occurring PAP forms. In previous work the $\mathrm{Zn}^{\mathrm{II}}$ for $\mathrm{Fe}^{\mathrm{II}}$ substituted active site of pig PAP has been found to behave similarly to the $\mathrm{Zn}^{\mathrm{II}} \mathrm{Fe}^{\mathrm{III}}$ site of $\mathrm{kbPAP},{ }^{6}$ and similarly $\mathrm{Fe}^{\mathrm{II}}$ for $\mathrm{Zn}^{\mathrm{II}}$ substituted kbPAP gives a catalytically active $\mathrm{Fe}^{\mathrm{II}} \mathrm{Fe}^{\mathrm{III}}$ form. ${ }^{20}$

\section{Experimental Section}

Isolation of PAP (Uteroferrin). Uteroferrin was obtained from the allantoic fluid of a sow at mid-pregnancy and purified according to literature procedures. ${ }^{5,18}$ The purified $\mathrm{Fe}^{\mathrm{III}} \mathrm{Fe}^{\mathrm{III}}$ protein was reduced to the $\mathrm{Fe}^{\mathrm{II}} \mathrm{Fe}^{\mathrm{III}}$ state by addition of ascorbate $(0.10 \mathrm{M})$ and dialyzed for $4 \mathrm{~h}$ against ammonium iron(II) sulfate $(6 \mathrm{mM})$ at $\mathrm{pH}$ 5.0 (50 $\mathrm{mM}$ sodium acetate). This was followed by desalting on a Sephadex G25 column, and the buffer was exchanged using an Amicon filter with a PM10 membrane. The UV-vis absorbance (A) ratio for $\mathrm{Fe}^{\mathrm{II}} \mathrm{Fe}^{\mathrm{III}} \mathrm{Uf}$ at different wavelengths $A_{280} / A_{515}$ gave a value of less than $15: 1$ as required. ${ }^{18}$ The protein was dialyzed against $40 \mathrm{mM}$ acetate buffer at $\mathrm{pH} 4.9$ and concentrated by Amicon filtration. Any remaining phosphate was removed from $\mathrm{Fe}^{\mathrm{II}} \mathrm{Fe}^{\mathrm{III}} \mathrm{Uf}$ solutions by further desalting, and the final UV-vis spectrum corresponded to that of $\mathrm{Fe}^{\mathrm{II}} \mathrm{Fe}^{\mathrm{III}}$ Uf. The concentrated protein solution was separated into $1 \mathrm{~mL}$ aliquots and stored frozen at -80 ${ }^{\circ} \mathrm{C}$ under air.

Other Reagents. The following reagents were used as supplied: potassium dihydrogen (ortho)phosphate, $\mathrm{KH}_{2} \mathrm{PO}_{4}$ (Sigma); sodium dithionite (also referred to as hydrosulfite), $\mathrm{Na}_{2} \mathrm{~S}_{2} \mathrm{O}_{4}$

(16) Averill, B. A.; Davis, J. C.; Burman, S.; Zirino, T.; Sanders-Loehr, J.; Moehr, T. M.; Sage, J. T.; Debrunner, P. G. J. Am. Chem. Soc. 1987, 109, 3760.

(17) Yang, Y.-S.; McCormick, J. M.; Solomon, E. I. J. Am. Chem. Soc. 1997, 119, 11832

(18) Aquino, M. A. S.; Lim, J.-S.; Sykes, A. G. J. Chem. Soc. Dalton Trans. 1992, 2135. (b) Aquino, M. A. S.; Lim, J.-S.; Sykes, A. G. J. Chem Soc., Dalton Trans. 1994, 429.

(19) Merkx, M.; Pinkse, M. W. H.; Averill, B. A. Biochemistry 1999, 38, 9914.

(20) Suerbaum, H.; Körner, M.; Witzel, H.; Althaus, E.; Mosel, B.-D.; Müller-Warmuth, W. Eur. J. Biochem. 1993, 214, 313. 
(Sigma); 2-mercaptoethanol, $\mathrm{HSCH}_{2} \mathrm{CH}_{2} \mathrm{OH}$ (Aldrich); zinc(II) sulfate, $\mathrm{ZnSO}_{4} \cdot 7 \mathrm{H}_{2} \mathrm{O}$ (Sigma); nickel chloride, $\mathrm{NiCl}_{2} \cdot 6 \mathrm{H}_{2} \mathrm{O}$ (Aldrich); cobalt(II) chloride, $\mathrm{CoCl}_{2} \cdot 6 \mathrm{H}_{2} \mathrm{O}(\mathrm{BDH})$; copper(II) sulfate, $\mathrm{CuSO}_{4} \cdot 5 \mathrm{H}_{2} \mathrm{O}$ (Sigma); manganese(II) sulfate, $\mathrm{MnSO}_{4} \cdot \mathrm{H}_{2} \mathrm{O}$ (Sigma); bathophenanthroline disulfonic acid, 4,7-diphenyl-1,10-phenanthroline disulfonic acid, $\mathrm{Na}_{2} \mathrm{C}_{24} \mathrm{H}_{14} \mathrm{~N}_{2} \mathrm{O}_{6} \mathrm{~S}_{2}$, referred to here as DPSphen (Sigma); 2,2'-biquinoline, $\mathrm{C}_{18} \mathrm{H}_{12} \mathrm{~N}_{2}$ (Sigma); sodium periodate, $\mathrm{NaIO}_{4}$ (Analar, $\mathrm{BDH}$ ). The disodium dihydrogen salt of edta (ethylenediaminetetraacetate) was used (Sigma). Stock solutions of phosphate were made up with the appropriate buffer (see below). Acid dissociation $\mathrm{p} K_{\mathrm{a}}$ values for $\mathrm{H}_{3} \mathrm{PO}_{4}$ (2.12) and $\mathrm{H}_{2} \mathrm{PO}_{4}^{-}$(6.7) indicate $\mathrm{H}_{2} \mathrm{PO}_{4}{ }^{-}$as the dominant reactant species for the range of $\mathrm{pH}$ values studied. ${ }^{18}$ Monodentate and bridging phosphate products are assumed to be present as $\mathrm{HPO}_{4}{ }^{2-}$ at $\mathrm{pH} 4.9$; see, e.g., ref 21.

Buffers. Buffers $(40 \mathrm{mM})$ used were as follows: glycine- $\mathrm{HCl}$, pH 2.5-3.2; acetate-acetic acid, $\mathrm{pH} 3.2-5.6$; and [bis(2-hydroxyethyl)amino]-[tris(hydroxymethyl)methane] (bis-tris)/(HCl), $\mathrm{pH} 5.6-$ 6.2, all from Sigma. Previously the effect of acetate (which is potentially coordinating) was tested by variations in the range $25-$ $55 \mathrm{mM}$, without any effect being observed..$^{18}$ Here runs were carried out with no acetate present using 4-chloroaniline (Lancaster Chemicals; $\mathrm{p} K_{\mathrm{a}}$ 3.98) as buffer at $\mathrm{pH}$ 4.9. All buffer solutions were prepared using water that had been singly distilled, and then passed down a deionizer column.

Procedure for PAP Substitution. The procedure for the conversion of $\mathrm{Fe}^{\mathrm{II}} \mathrm{Fe}^{\mathrm{III}}$ enzyme to the apo- $\mathrm{Fe}^{\mathrm{III}}$ containing product has been described. ${ }^{10,11}$ This required the addition of a $10 \mu \mathrm{L}$ aliquot of freshly prepared $1 \mathrm{M}$ sodium dithionite to $1 \mathrm{~mL}$ of protein (60$300 \mu \mathrm{M})$ at $\mathrm{pH} 4.9(100 \mathrm{mM}$ acetate $)$ to give $\left[\mathrm{S}_{2} \mathrm{O}_{4}{ }^{2-}\right](10 \mathrm{mM})$ under anaerobic conditions. After $1 \mathrm{~min}$ the mixture was separated using a small desalting column $(150 \times 5 \mathrm{~mm}$, P6-DG desalting resin, BioRad). Within 2 min of elution metal-substituted PAP derivatives $\mathrm{Mn}^{\mathrm{II}} \mathrm{Fe}^{\mathrm{III}}, \mathrm{Co}^{\mathrm{II}} \mathrm{Fe}^{\mathrm{III}}, \mathrm{Ni}^{\mathrm{II}} \mathrm{Fe}^{\mathrm{III}}, \mathrm{Cu}^{\mathrm{II}} \mathrm{Fe}^{\mathrm{III}}$, and $\mathrm{Zn}^{\mathrm{II}} \mathrm{Fe}^{\mathrm{III}}$ respectively were generated by adding the $\mathrm{M}^{\mathrm{II}}$ metal ion (50-650fold excess) to the apo-Fe III form $(\sim 1 \mathrm{~mL} ; 150-300 \mu \mathrm{M})$. $\beta$-Mercaptoethanol $(0.12 \mathrm{M})$ was added in the case of $\mathrm{Mn}$ and $\mathrm{Zn}$ to facilitate metal uptake. ${ }^{10}$ After $\sim 48 \mathrm{~h}$ the solution was again passed down a small desalting column and the metal-substituted derivative collected. Uptake of close to 2 equiv of $\mathrm{Cu}^{\mathrm{II}}$ was observed, and treatment with edta was required to produce Uf that contained 1 equiv only of $\mathrm{Cu}^{\mathrm{II}}$.

Metal Analyses of $\mathrm{Fe}^{\mathrm{II}} \mathrm{Fe}^{\mathrm{III}}$ Uf PAP by ICP and Atomic Spectroscopy. Samples were prepared by digestion of a $1 \mathrm{~mL}$ sample with $1 \mathrm{~mL}$ of freshly prepared 1:1 solution of $30 \%$ hydrogen peroxide/concentrated nitric acid at $70{ }^{\circ} \mathrm{C}$ for $5 \mathrm{~h}$ until the solution became clear. The solution was cooled, diluted to $5 \mathrm{~mL}$ in a volumetric flask, and analyzed by an inductively coupled plasma (ICP) technique (using a Perkin-Elmer Plasma 1000) and by atomic absorption (Shimadzu AA-6502S). A sample of distilled water (1.0 $\mathrm{mL}$ ) was digested in the same way and used as blank. Analysis for Fe gave exactly two per mole of PAP. Some Zn $(\sim 7 \%)$ was detected, but $\mathrm{Cu}$ and $\mathrm{Mn}$ were below detection limits. Analyses for $\mathrm{Zn}^{\mathrm{II}} \mathrm{Fe}^{\mathrm{III}} \mathrm{Uf}$ were also carried out.

PAP Metal Analyses by UV-Vis. The following additional procedures were used.

(a) $\mathrm{Fe}^{\mathrm{II}} / \mathrm{Fe}^{\mathrm{III}}$ Content. The total Fe content was determined by reduction followed by complexation with DPS-phen. ${ }^{22}$ The DPSphen $(0.4 \mathrm{mg})$ was dissolved in glacial acetic acid $(400 \mu \mathrm{L})$ and

(21) Edwards, J. D.; Foong, S.-W.; Sykes, A. G. J. Chem. Soc., Dalton Trans. 1973, 829

(22) Zak, B. Am. J. Clin. Pathol. 1958, 29, 590. then added to the protein $(500 \mu \mathrm{L})$, which contained a small aliquot of $\mathrm{L}$-cysteine to reduce the $\mathrm{Fe}^{\mathrm{III}}$ to $\mathrm{Fe}^{\mathrm{II}}$. The total $\mathrm{Fe}$ was obtained by determining the absorbance of the $\left[\mathrm{Fe}(\mathrm{DPS}-\mathrm{phen})_{3}\right]^{2+}$ complex at $535 \mathrm{~nm}\left(\epsilon=2.21 \times 10^{4} \mathrm{M}^{-1} \mathrm{~cm}^{-1}\right)$.

(b) $\mathrm{Cu}^{\mathrm{II}}$ Content. The $\mathrm{Cu}^{\mathrm{II}}$ of $\mathrm{Cu}^{\mathrm{II}} \mathrm{Fe}^{\mathrm{III}}$ Uf was determined by the Klotz method. ${ }^{23,24}$ The reagent was prepared by adding $2,2^{\prime}$ biquinoline $(50 \mathrm{mg})$ to glacial acetic acid $(100 \mathrm{~mL})$. To a sample of $\mathrm{Cu}^{\mathrm{II}} \mathrm{Fe}^{\mathrm{III}} \mathrm{Uf}(500 \mu \mathrm{L})$ was added a small aliquot of L-cysteine in glacial acetic acid ( $100 \mu \mathrm{L})$ to reduce the $\mathrm{Cu}^{\mathrm{II}}$ to $\mathrm{Cu}^{\mathrm{I}}$, followed by 2,2'-biquinoline solution $(400 \mu \mathrm{L})$. The total $\mathrm{Cu}$ was determined as $\mathrm{Cu}^{\mathrm{I}}$ by measuring the absorbance at $540 \mathrm{~nm}\left(\epsilon=6800 \mathrm{M}^{-1}\right.$ $\mathrm{cm}^{-1}$ ).

(c) $\mathrm{Co}^{\mathrm{II}}$ Content. The $\mathrm{Co}^{\mathrm{II}}$ of a solution of $\mathrm{Co}^{\mathrm{II}} \mathrm{Fe}^{\mathrm{III}}$ Uf $(100$ $\mu \mathrm{L})$ was determined by addition of $11.3 \mathrm{M} \mathrm{HCl}(900 \mu \mathrm{L})$ to give $10.2 \mathrm{M} \mathrm{HCl}$. After $2 \mathrm{~min}$ the blue color of tetrahedral $\mathrm{Co}^{\mathrm{II}}$ species developed. Three major UV-vis peaks were observed at 624, 662, and $691 \mathrm{~nm}$. From 10.2 M HCl solutions of known $\mathrm{Co}^{\mathrm{II}}$ content, $\epsilon$ values of $350(10), 500(10)$, and $540(10) \mathrm{M}^{-1} \mathrm{~cm}^{-1}$ respectively (errors in parentheses) were determined, and served to standardize the procedure.

(d) $\mathrm{Mn}^{\mathrm{II}}$ Content. The $\mathrm{Mn}^{\mathrm{II}}$ present in $\mathrm{Mn}^{\mathrm{II}} \mathrm{Fe}^{\mathrm{III}}$ Uf was determined by oxidation to permanganate with $\mathrm{NaIO}_{4}{ }^{25}$ To the protein sample $(1 \mathrm{~mL})$ was added $18 \mathrm{M} \mathrm{H}_{2} \mathrm{SO}_{4}(100 \mu \mathrm{L})$, followed by $\mathrm{NaIO}_{4}(10 \mathrm{mg})$, and the solution was heated for $10 \mathrm{~min}$. After cooling, the purple colored permanganate solution was made up to $1.1 \mathrm{~mL}$ and the UV-vis spectrum recorded. Three peaks were observed at 507, 525, and $545 \mathrm{~nm}$. From solutions of known $\mathrm{Mn}^{\mathrm{II}}$ content, $\epsilon$ values of 1840(10), 2420(20), and 2300(20) $\mathrm{M}^{-1} \mathrm{~cm}^{-1}$ respectively were determined.

PAP Metal Analyses by Electrochemical Method. A Princeton Applied Research 173 potentiostat interfaced to an Elonex 486 IBM PC was used with EG \& G software. Measurements were made at a gold disk electrode, which was polished prior to each experiment using an alumina powder (BDH, Analar, $0.3 \mu \mathrm{m}$ diameter)/water slurry. The reference was an $\mathrm{Ag} / \mathrm{AgCl}(1 \mathrm{M} \mathrm{KCl})$ electrode in conjunction with a Pt-wire counter electrode.

(a) $\mathrm{Cu}^{\mathrm{II}}$ Content. The $\mathrm{Cu}^{\mathrm{II}}$ of $\mathrm{Cu}^{\mathrm{II}} \mathrm{Fe}^{\mathrm{III}}$ Uf was determined for aqueous protein solutions $(1 \mathrm{~mL})$ in glacial acetic acid $(1 \mathrm{~mL})$ by measurement of cyclic voltammogram peak heights. Scans were carried out over the range 700 to $-300 \mathrm{mV}$ at a rate of $100 \mathrm{mV} / \mathrm{s}$. The potential was held at $-300 \mathrm{mV}$ for $60 \mathrm{~s}$ to allow $\mathrm{Cu}$ metal to plate onto the electrode.

(b) $\mathrm{Ni}^{\mathrm{II}}$ Content. The $\mathrm{Ni}^{\mathrm{II}}$ component of $\mathrm{Ni}^{\mathrm{II}} \mathrm{Fe}^{\mathrm{III}}$ Uf was determined by the same procedure as for $\mathrm{Cu}^{\mathrm{II}}$. Scans were made over the range 0 to $-500 \mathrm{mV}$ at a rate of $100 \mathrm{mV} / \mathrm{s}$. The potential was in this case held at $-500 \mathrm{mV}$ for $120 \mathrm{~s}$.

Procedure for Determining Formation Constants for $\mathrm{H}_{2} \mathrm{PO}_{4}{ }^{-}$ Binding to Uf. Overall formation constants $K\left(25^{\circ} \mathrm{C}\right)$ for the reaction of $\mathrm{H}_{2} \mathrm{PO}_{4}{ }^{-}$with $\mathrm{Fe}^{\mathrm{II}} \mathrm{Fe}^{\mathrm{III}}$ Uf were determined by $\mathrm{UV}-$ vis titrations at $680 \mathrm{~nm}$ (eq 5). Conditions were with protein (15-50

$$
\mathrm{Fe}^{\mathrm{II}} \mathrm{Fe}^{\mathrm{III}}+\mathrm{H}_{2} \mathrm{PO}_{4} \stackrel{\mathrm{K}}{\rightleftharpoons} \mathrm{Fe}^{\mathrm{II}} \mathrm{Fe}^{\mathrm{III}} \mu\left(\mathrm{HPO}_{4}{ }^{2-}\right)+\mathrm{H}^{+}
$$

$\mu \mathrm{M})$ at $\mathrm{pH} 4.9(40 \mathrm{mM}$ buffer $), I=0.100 \mathrm{M}(\mathrm{NaCl})$. Absorbance changes were monitored on a Shimadzu 2101 PC spectrophotometer as small (microsyringe) aliquots of phosphate $(200 \mathrm{mM})$ were added, final $\left[\mathrm{H}_{2} \mathrm{PO}_{4}^{-}\right]$in the range $0.2-4.0 \mathrm{mM}, I=0.100 \mathrm{M}$

(23) Klotz, I. M.; Klotz, T. A. Science 1955, 121, 477

(24) Felsenfeld, G. Arch. Biochem. Biophys. 1960, 87, 247.

(25) Willard, H. H.; Greathouse, L. H. J. Am. Chem. Soc. 1917, 39, 2366. 
Twitchett et al.

Table 1. Metal Analyses for Different $\mathrm{M}^{\mathrm{II}} \mathrm{Fe}^{\mathrm{III}}$ Uf PAP Active Sites by Colorimetric or Electrochemical Methods (Error Range in Parentheses), Together with UV-Vis Peak Position $(\lambda / \mathrm{nm})$ and Absorption Coefficients $\left(\epsilon / \mathrm{M}^{-1} \mathrm{~cm}^{-1}\right)$ at $\mathrm{pH} 4.9$ (40 mM Acetate), $I=0.100$ $(\mathrm{NaCl})$

\begin{tabular}{lllcc}
\hline active site & $\mathrm{Fe} / \mathrm{mol}$ & $\mathrm{M}^{\mathrm{II}} / \mathrm{mol}$ & $\lambda$ & $\epsilon$ \\
\hline $\mathrm{Fe}^{\mathrm{II}} \mathrm{Fe}^{\mathrm{III}}$ & $1.94(3)$ & & 510 & 4450 \\
$\mathrm{Fe}^{\mathrm{III}} \mathrm{Fe}^{\mathrm{III}}$ & $1.91(4)$ & & 550 & 4300 \\
apo- $\mathrm{Fe}$ & $0.91(4)$ & & 545 & 3190 \\
$\mathrm{Mn}^{\mathrm{II}} \mathrm{Fe}^{\mathrm{III}}$ & $0.93(3)$ & $1.10(8)$ & 514 & 3350 \\
$\mathrm{Co}^{\mathrm{II}} \mathrm{Fe}^{\mathrm{III}}$ & $0.85(4)$ & $0.81(5)$ & 518 & 3370 \\
$\mathrm{Ni}^{\mathrm{II}} \mathrm{Fe}^{\mathrm{III}}$ & $0.80(6)$ & $0.81(6)^{a}$ & 510 & 3260 \\
$\mathrm{Cu}^{\mathrm{II}} \mathrm{Fe}^{\mathrm{III}}$ & $0.79(5)$ & $0.96(7)$ & 545 & 3400 \\
$\mathrm{Zn}^{\mathrm{II}} \mathrm{Fe}^{\mathrm{III}}$ & $0.76(4)$ & $0.80(6)^{b}$ & 525 & 3580
\end{tabular}

${ }^{a}$ Electrochemical method. ${ }^{b}$ See also ref 10

$(\mathrm{NaCl})$. The data were fitted to eq 6 ,

$$
\frac{1}{\left(A_{0}-A_{\mathrm{obs}}\right)}=\frac{K}{\left[\mathrm{H}_{2} \mathrm{PO}_{4}^{-}\right]\left(A_{0}-A_{\mathrm{p}}\right)}+\frac{1}{\left(A_{0}-A_{\mathrm{p}}\right)}
$$

where $A_{0}$ and $A_{\mathrm{p}}$ are absorbance values for $\mathrm{Fe}^{\mathrm{II}} \mathrm{Fe}^{\mathrm{III}}$ and $\mathrm{Fe}^{\mathrm{II}} \mathrm{Fe}^{\mathrm{III}} \mu$ $\left(\mathrm{HPO}_{4}{ }^{2-}\right)$, respectively, and $A_{\mathrm{obs}}$ is the experimental value at a particular $\left[\mathrm{H}_{2} \mathrm{PO}_{4}^{-}\right]$. A similar procedure was used for the determination of $K$ for the reaction of $\mathrm{H}_{2} \mathrm{PO}_{4}{ }^{-}$with different $\mathrm{M}^{\mathrm{II}} \mathrm{Fe}^{\mathrm{III}}$ Uf derivatives.

Kinetic Procedures. The reactions of $\mathrm{Fe}^{\mathrm{II}} \mathrm{Fe}^{\mathrm{III}}$ Uf and $\mathrm{M}^{\mathrm{II}} \mathrm{Fe}^{\mathrm{III}}$ derivatives with $\mathrm{H}_{2} \mathrm{PO}_{4}{ }^{-}$were monitored at wavelengths $\sim 680 \mathrm{~nm}$ using an Applied Photophysics SX-17MV stopped-flow spectrophotometer. Absorbance vs time changes gave satisfactory uniphasic first-order fits, and hence rate constants $k_{\mathrm{obs}}$ using Applied Photophysics software. Average $k_{\mathrm{obs}}$ values from five triggerings were recorded. Protein concentrations were generally $\sim 45 \mu \mathrm{M}$, and $\left[\mathrm{H}_{2} \mathrm{PO}_{4}^{-}\right]$values in the range $3.8-50 \mathrm{mM}$. The temperature was $25.0 \pm 0.1^{\circ} \mathrm{C}$, and the ionic strength adjusted to $I=0.100 \pm 0.001$ $\mathrm{M}$ with $\mathrm{NaCl}$. From studies on the reaction of $\alpha$-naphthyl phosphate with $\mathrm{Fe}^{\mathrm{II}} \mathrm{Fe}^{\mathrm{III}} \mathrm{Uf}$ in which the formation of $\alpha$-naphthol at $323 \mathrm{~nm}$ was monitored, maximum activity is observed at $\mathrm{pH} 4.9 .{ }^{18}$ This $\mathrm{pH}$ applies also to studies on $\mathrm{M}^{\mathrm{II}} \mathrm{Fe}^{\mathrm{III}}$ Uf. However because of the mechanism proposed, an extension of the simple enzyme kinetic treatment may not apply, and more detailed activity studies are not considered in this work. Linear and nonlinear data fitting was carried out using the software Mac Curve Fit, version 1.1.2 (Kevin Raner Software).

\section{Results}

Characterization of Metal-Substituted Uteroferrin Derivatives. The metal ion content and $\mathrm{UV}-$ vis peaks/ absorption coefficients (based on $\mathrm{Fe}^{\mathrm{III}}$ content) for $\mathrm{Fe}^{\mathrm{II}} \mathrm{Fe}^{\mathrm{III}}$, $\mathrm{Fe}^{\mathrm{III}} \mathrm{Fe}^{\mathrm{III}}$, apo-Fe ${ }^{\mathrm{III}}$, and metal-substituted $\mathrm{M}^{\mathrm{II}} \mathrm{Fe}^{\mathrm{III}}$ Uf derivatives are as listed in Table 1. All metal determinations were an average of at least three values, with standard deviations as indicated. The derivatives contain close to one $\mathrm{Fe}^{\mathrm{III}}$ to one atom of $\mathrm{M}^{\mathrm{II}}$ per molecule of enzyme. An exception was with the initial $\mathrm{Cu}^{\mathrm{II}}$ product. Following a typical reconstitution procedure, two $\mathrm{Cu}^{\mathrm{II}}$ atoms per enzyme were incorporated per iron. To remove one of the $\mathrm{Cu}^{\mathrm{II}}$ 's, edta $(100 \mu \mathrm{M})$ was added to the protein solution, which was allowed to stand for $\sim 30 \mathrm{~s}$ before being passed down a desalting column. The activity of the $\mathrm{Cu}^{\mathrm{II}} \mathrm{Fe}^{\mathrm{III}} \mathrm{Uf}$ before and after edta treatment was similar (see later), indicating that the active-site copper is selectively retained. The second $\mathrm{Cu}^{\mathrm{II}}$ binds less strongly

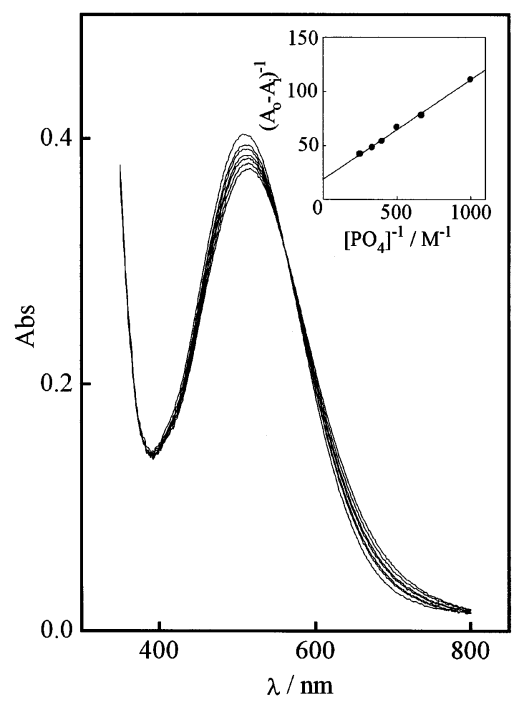

Figure 3. Determination of $\mathrm{K}\left(25^{\circ} \mathrm{C}\right)$ by titration of $0.20 \mathrm{M} \mathrm{H}_{2} \mathrm{PO}_{4}{ }^{-}$ $(0-4 \mathrm{mM})$ with in this example $\mathrm{Co}^{\mathrm{II}} \mathrm{Fe}^{\mathrm{III}} \mathrm{Uf}(\sim 120 \mu \mathrm{M})$ at $\mathrm{pH} 4.90$. The absorbance $(A)$ at $\sim 518 \mathrm{~nm}$ increases as $\mathrm{H}_{2} \mathrm{PO}_{4}{ }^{-}$is added, $I=0.100 \mathrm{M}$ $(\mathrm{NaCl})$. The inset plot of absorbance changes at $680 \mathrm{~nm}$ according to eq 6 allows $K$ to be determined.

at an alternative site on the protein. The $\mathrm{M}^{\mathrm{II}}$ products are different shades of purple consistent with retention of the dominant tyrosine phenolate to $\mathrm{Fe}^{\mathrm{III}}$ ligand to metal chargetransfer (LMCT) transition. ${ }^{26}$ The $500-550 \mathrm{~nm}$ peak absorption coefficients fall into two categories: those for the $\mathrm{Fe}^{\mathrm{II}} \mathrm{Fe}^{\mathrm{III}}$ and $\mathrm{Fe}^{\mathrm{III}} \mathrm{Fe}^{\mathrm{III}}$ protein, which are $\sim 4400 \mathrm{M}^{-1} \mathrm{~cm}^{-1}$, and those for other $\mathrm{M}^{\mathrm{II}} \mathrm{Fe}^{\mathrm{III}} \mathrm{Uf}$ forms, which are $\sim 25 \%$ smaller.

Formation Constants $\mathrm{K}$ for $\mathrm{H}_{2} \mathrm{PO}_{4}{ }^{-}$Binding to $\mathrm{M}^{\mathrm{II}} \mathrm{Fe}^{\mathrm{III}}$ Uf. These, as defined in eq 5 , were determined by UV-vis titration, absorbance changes as in Figure 3. Two stages, eqs 7 and 8, are proposed, with $K=K_{1} K_{2}$. No evidence was

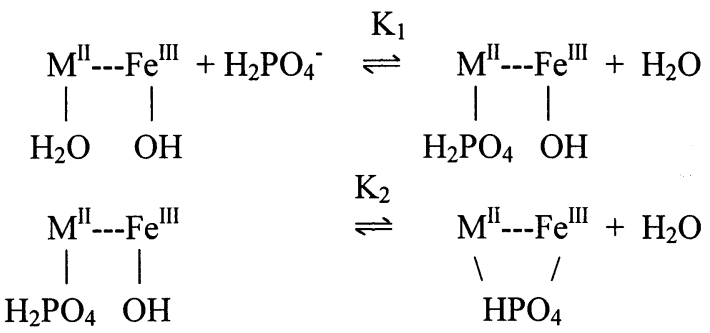

obtained for an $\left[\mathrm{H}_{2} \mathrm{PO}_{4}{ }^{-}\right]^{2}$ dependence. Diphosphate $\mathrm{M}^{\mathrm{II}} \mathrm{Fe}^{\mathrm{III}}$ products are assumed to absorb less strongly than $\mu$-phosphate products, with eq 5 defining the major part of absorbance changes observed. Values of $K$, Table 2, increase as the $\mathrm{pH}$ increases from 3.55 to 6.60 . Acid dissociation of the $\mathrm{Fe}^{\mathrm{III}}-\mathrm{H}_{2} \mathrm{O}$ is proposed to account for this trend.

Variation of Rate Constants $\boldsymbol{k}_{\text {obs }}$ for $\mathrm{M}^{\mathrm{II}} \mathrm{Fe}^{\mathrm{III}}$ Uf with $\left[\mathbf{H}_{2} \mathbf{P O}_{4}{ }^{-}\right]$. Values of $k_{\mathrm{obs}}$ in Table $1 \mathrm{~S}$ (Supporting Information) include a set in which the acetate buffer was replaced by 4-chloroaniline. This replacement has no effect on $k_{\mathrm{obs}}$, Figure 4, and it can be concluded that acetate does not coordinate appreciably. ${ }^{18}$ At $\mathrm{pH} 4.9$ first-order rate constants

(26) Doi, K.; McCracken, J.; Peisach, J.; Aisen, P. J. Biol. Chem. 1988, 263, 5757. 
Table 2. Formation Constants $K\left(25^{\circ} \mathrm{C}\right)$ for $\mathrm{H}_{2} \mathrm{PO}_{4}{ }^{-}$Binding to $\mathrm{Fe}^{\mathrm{II}} \mathrm{Fe}^{\mathrm{III}}$ Uf and $\mathrm{M}^{\mathrm{II}} \mathrm{Fe}^{\mathrm{III}}$ Uf $(15-50 \mu \mathrm{M}), 40 \mathrm{mM}$ Acetate Buffer, $I=$ $0.100 \mathrm{M}(\mathrm{NaCl})$ (Standard Deviations in Parentheses)

\begin{tabular}{ccc}
\hline protein & $\mathrm{pH}$ & $K / \mathrm{M}^{-1}$ \\
\hline $\mathrm{Fe}^{\mathrm{II}} \mathrm{Fe}^{\mathrm{III}}$ & 3.55 & $80(10)$ \\
& 4.90 & $165(25)^{a}$ \\
& $6.60^{b}$ & $1140(160)$ \\
$\mathrm{Mn}^{\mathrm{II}} \mathrm{Fe}^{\mathrm{III}}$ & 4.90 & $740(50)$ \\
$\mathrm{Co}^{\mathrm{II}} \mathrm{Fe}^{\mathrm{III}}$ & 4.90 & $190(30)$ \\
$\mathrm{Ni}^{\mathrm{II}} \mathrm{Fe}^{\mathrm{III}}$ & 4.90 & $90(10)$ \\
$\mathrm{Cu}^{\mathrm{II}} \mathrm{Fe}^{\mathrm{III}}$ & 4.90 & $800(55)$ \\
$\mathrm{Zn}^{\mathrm{II}} \mathrm{Fe}^{\mathrm{III}}$ & 4.90 & $380(30)$
\end{tabular}

${ }^{a}$ Previous values in range $83-313 \mathrm{M}^{-1} .{ }^{b}$ Bis-tris buffer.

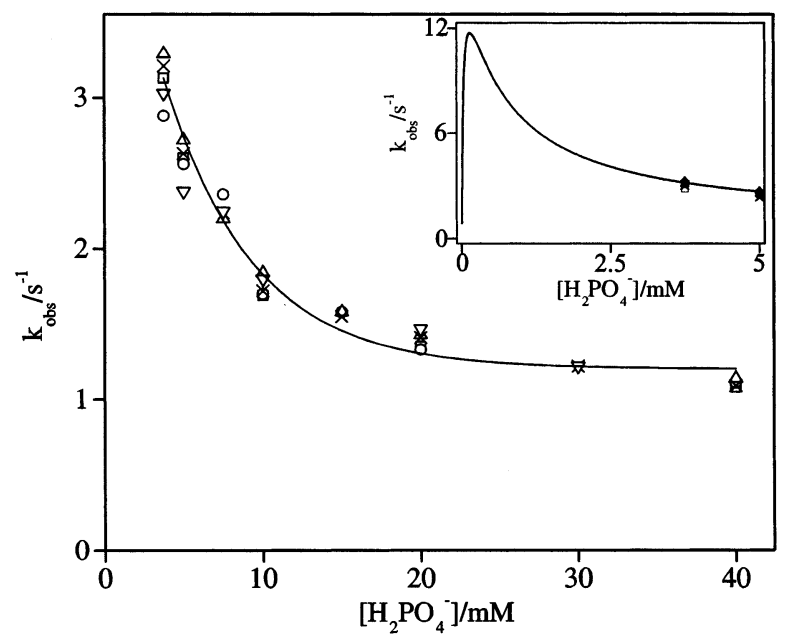

Figure 4. The variation of first-order rate constants $k_{\mathrm{obs}}\left(25^{\circ} \mathrm{C}\right)$ with $\left[\mathrm{H}_{2} \mathrm{PO}_{4}^{-}\right]$for the reaction of $\mathrm{Fe}^{\mathrm{II}} \mathrm{Fe}^{\mathrm{III}} \mathrm{Uf}(10-40 \mu \mathrm{M})$ with $\mathrm{H}_{2} \mathrm{PO}_{4}{ }^{-}$at $\mathrm{pH}$ $4.9, I=0.100 \mathrm{M}(\mathrm{NaCl})$. Different data sets $\square$ (air-free), $\bigcirc, \Delta$ and $\times$ (in air), all using $45 \mathrm{mM}$ acetate buffer, and $\nabla$ with $18 \mathrm{mM}$ 4-chloroaniline buffer (also in air), indicate satisfactory reproducibility. The solid line generated by fitting to eq 10 is shown, and in the inset this is extended to low $\left[\mathrm{H}_{2} \mathrm{PO}_{4}^{-}\right]$.

$k_{\text {obs }}$ for the reaction of $\mathrm{H}_{2} \mathrm{PO}_{4}{ }^{-}$with $\mathrm{Fe}^{\mathrm{II}} \mathrm{Fe}^{\mathrm{III}} \mathrm{Uf}$ monitored at $620 \mathrm{~nm}$ show little dependence on $\left[\mathrm{H}_{2} \mathrm{PO}_{4}{ }^{-}\right]$in the range 25-45 mM, as observed previously. ${ }^{18}$ At $\left[\mathrm{H}_{2} \mathrm{PO}_{4}{ }^{-}\right]<20$ $\mathrm{mM}$, however, an upward trend in $k_{\mathrm{obs}}$ is apparent and is reproducible under different conditions. Similar behavior is observed for the $\mathrm{M}^{\mathrm{II}}$ substituted derivatives, Table $2 \mathrm{~S}$ (Supporting Information) and Figure 5. Errors for $k_{\mathrm{obs}}$ (Tables $1 \mathrm{~S}$ and $2 \mathrm{~S}$ ) are $\pm 9 \%$ at low $\mathrm{pH}$ and $\pm 3 \%$ at higher $\mathrm{pH}$. A satisfactory fit to the empirical eq 9 is obtained, Figure 6.

$$
k_{\mathrm{obs}}=A\left[\mathrm{H}_{2} \mathrm{PO}_{4}^{-}\right]^{-1}+B
$$

Since $k_{\mathrm{obs}}=0$ at $\left[\mathrm{H}_{2} \mathrm{PO}_{4}^{-}\right]=0$, a dependence as in Figure 4 (inset) is indicated, and an inhibition step $K_{\mathrm{i}}$ is included in the reaction sequence (Scheme 1), from which eq 10 is obtained.

$$
\begin{aligned}
k_{\mathrm{obs}}=k_{\mathrm{f}}\left\{K_{1}\left[\mathrm{H}_{2} \mathrm{PO}_{4}^{-}\right]\right\} /\left\{1+K_{1}\left[\mathrm{H}_{2} \mathrm{PO}_{4}{ }^{-}\right]+\right. \\
\left.K_{1} K_{\mathrm{i}}\left[\mathrm{H}_{2} \mathrm{PO}_{4}^{-}\right]^{2}+K_{1} \mathrm{~K}_{2}\left[\mathrm{H}_{2} \mathrm{PO}_{4}^{-}\right]\right\}+k_{\mathrm{b}}
\end{aligned}
$$

At high $\left[\mathrm{H}_{2} \mathrm{PO}_{4}{ }^{-}\right]$this simplifies to the same form as eq 9 with $A$ and $B$ respectively $k_{\mathrm{f}} / K_{\mathrm{i}}$ and $k_{\mathrm{b}}$. An examination of the fit (inset to Figure 4) makes clear the extent to which data is extrapolated, and draws attention to uncertainties in the quality of the fit. Hence the algorithm for the fitting is

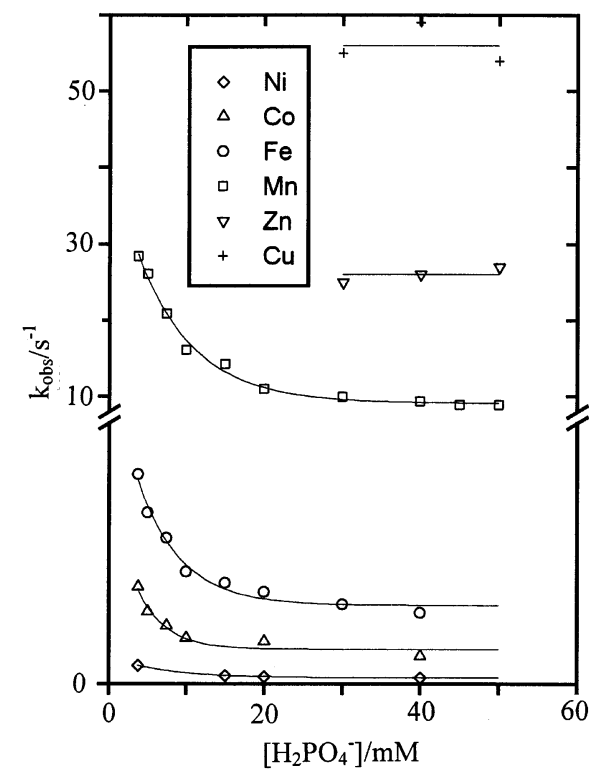

Figure 5. The variation of first-order rate constants $k_{\mathrm{obs}}\left(25^{\circ} \mathrm{C}\right)$ for the reactions of $\mathrm{M}^{\mathrm{II}} \mathrm{Fe}^{\mathrm{III}}$ Uf $(10-40 \mu \mathrm{M}), \mathrm{M}=\mathrm{Fe}^{\mathrm{II}}, \mathrm{Mn}^{\mathrm{II}}, \mathrm{Co}^{\mathrm{II}}, \mathrm{Ni}^{\mathrm{II}}, \mathrm{Cu}^{\mathrm{II}}, \mathrm{Zn}^{\mathrm{II}}$ with $\left[\mathrm{H}_{2} \mathrm{PO}_{4}^{-}\right]$at $\mathrm{pH} 4.9, I=0.100 \mathrm{M}(\mathrm{NaCl})$.

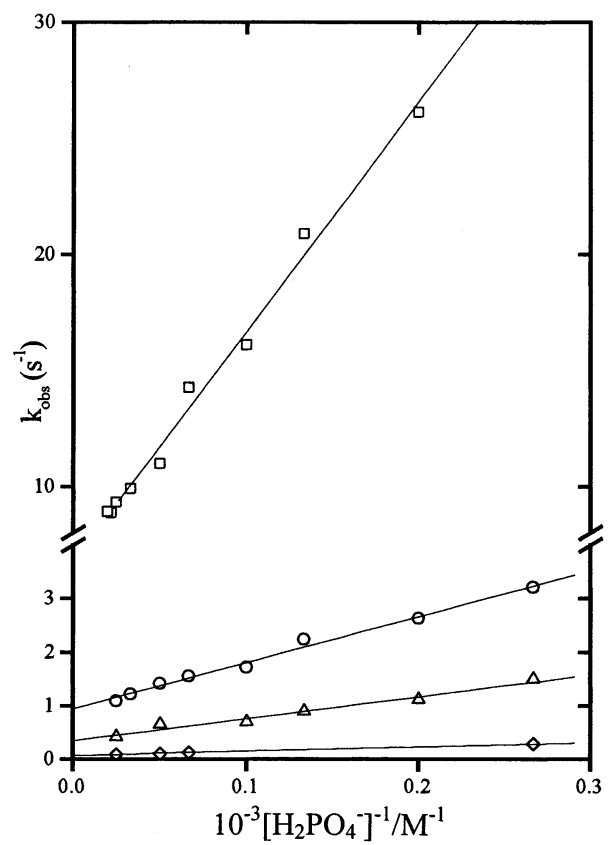

Figure 6. The variation of first-order rate constants $k_{\mathrm{obs}}\left(25^{\circ} \mathrm{C}\right)$ with $\left[\mathrm{H}_{2} \mathrm{PO}_{4}^{-}\right]^{-1}$ for the reaction of $\mathrm{H}_{2} \mathrm{PO}_{4}^{-}$with $\mathrm{Mn}^{\mathrm{II}} \mathrm{Fe}^{\mathrm{III}} \mathrm{Uf}(\square), \mathrm{Fe}^{\mathrm{II}} \mathrm{Fe} e^{\mathrm{III}} \mathrm{Uf}$ $(\mathrm{O}), \mathrm{Co}^{\mathrm{II}} \mathrm{Fe}^{\mathrm{III}}$ Uf $(\triangle)$, and $\mathrm{Ni}^{\mathrm{II}} \mathrm{Fe}^{\mathrm{III}}$ Uf $(\diamond)$, at $\mathrm{pH} 4.9$.

very sensitive to estimates of the fitted parameters. The following approach was taken to gain reasonable estimates. Approximate values for $k_{\mathrm{b}}$ were obtained from the linear plots in Figure 6 and were used as initial estimates in eq 10. Satisfactory fits were obtained with $K_{\mathrm{i}} \sim 10^{3} \mathrm{M}$. Finally, the number of variables was reduced by replacing $K_{2}$ by the ratio $k_{\mathrm{f}} / k_{\mathrm{b}}$. In the first round of fitting $k_{\mathrm{b}}$ and $K_{\mathrm{i}}$ were kept constant. This restriction was subsequently released to obtain an improved fit (fit 1 ). Last, $K_{2}$ was substituted back into eq 10 and the fit was rerun (fit 2 is shown in Figure 4). It turns out that $K_{\mathrm{i}}$ does not change significantly; furthermore the same fit was obtained when an initial value of $K_{\mathrm{i}}$ in the range 0.9-1.2 $\mathrm{mM}$ was chosen (data not shown). Likewise rate 
Twitchett et al.

Scheme 1

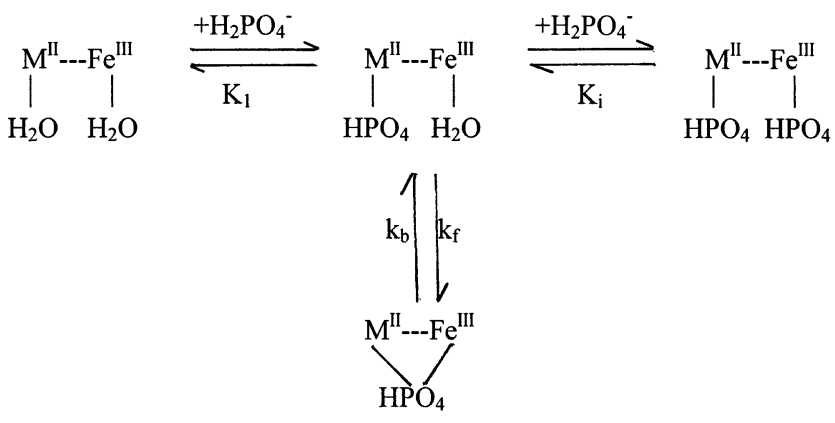

Table 3. Fit of Average Rate Constants $k_{\mathrm{obs}}$ at $\mathrm{pH} 4.9$ to Eq 10 (Weighted According to Spread at Each $\left[\mathrm{H}_{2} \mathrm{PO}_{4}{ }^{-}\right]$) Using a Fixed Value for $K_{\mathrm{i}}$ of $\sim 10^{3} \mathrm{M}^{-1}$; Other Terms as Defined in Scheme 1

\begin{tabular}{lclcc}
\hline derivative & $k_{\mathrm{f}} / \mathrm{s}^{-1}$ & $k_{\mathrm{b}} / \mathrm{s}^{-1}$ & $K_{1} / \mathrm{M}^{-1}$ & \multicolumn{1}{c}{$K_{2}$} \\
\hline $\mathrm{Fe}^{\mathrm{II}} \mathrm{Fe} \mathrm{e}^{\mathrm{III}} a$ & 6.9 & 0.91 & 27 & $7.8^{b}\left(7.6^{c}\right)$ \\
$\mathrm{Mn}^{\mathrm{II}} \mathrm{Fe}$ & 84.5 & 7.1 & 60 & $12.4^{b}\left(11.9^{c}\right)$ \\
$\mathrm{Co}^{\mathrm{III}} \mathrm{Fe}^{\mathrm{III}}$ & 4.1 & 0.36 & 18 & $12.1^{b}\left(11.4^{c}\right)$ \\
$\mathrm{Ni}^{\mathrm{II}} \mathrm{Fe}^{\text {III }}$ & 0.91 & 0.094 & 10 & $9.7^{b}\left(9.6^{c}\right)$
\end{tabular}
$1)$.

${ }^{a}$ Five data sets used, Table $1 \mathrm{~S} .{ }^{b}$ Fit 2 (see text). ${ }^{c}$ From ratio $k_{\mathrm{f}} / k_{\mathrm{b}}$ (Fit

constants for the opening of the $\mu$-phosphato bridge $k_{\mathrm{b}}$ in eq 10 are very similar (factor of 1.6), and are as listed in Table 3. Values of $K_{2}$ obtained from fit 1 and fit 2 are indicated, and a reasonable agreement is found.

Similar behavior is obtained at $\mathrm{pH}=4.6$, the $\mathrm{pH}$ used in earlier studies. ${ }^{18}$ Values of $k_{\mathrm{obs}}$ for the $\mathrm{M}^{\mathrm{II}} \mathrm{Fe}^{\mathrm{IIII}}$ reaction vary by $\sim 10^{3}$ at high $\left[\mathrm{H}_{2} \mathrm{PO}_{4}^{-}\right]$, ranging from $0.062 \mathrm{~s}^{-1}$ for $\mathrm{Ni}^{\mathrm{II}_{-}}$ $\mathrm{Fe}^{\mathrm{III}} \mathrm{Uf}$ to $57 \mathrm{~s}^{-1}$ for $\mathrm{Cu}^{\mathrm{II}} \mathrm{Fe}^{\mathrm{III}} \mathrm{Uf}$. Variations for the different $\mathrm{M}^{\mathrm{II}} \mathrm{Fe}^{\mathrm{III}}$ Uf derivatives are attributed to the different $\mathrm{M}^{\mathrm{II}}$ reactivities with $\left[\mathrm{H}_{2} \mathrm{PO}_{4}^{-}\right]$(i.e., $K_{1}$ ). No UV-vis changes were observed on addition of $\mathrm{H}_{2} \mathrm{PO}_{4}{ }^{-}$to apo- $\mathrm{Fe}^{\mathrm{III}}$ protein.

pH Dependence of Rate Constants $k_{\text {obs }}$ for $\mathrm{M}^{\mathrm{II}} \mathrm{Fe}^{\mathrm{III}} \mathrm{Uf}$ with $\mathbf{H}_{2} \mathbf{P O}_{4}{ }^{-}$. Here the $\mathrm{pH}$ dependences of rate constants for $\mathrm{Fe}^{\mathrm{II}} \mathrm{Fe}^{\mathrm{III}} \mathrm{Uf}, \mathrm{Zn}^{\mathrm{II}} \mathrm{Fe}^{\mathrm{III}} \mathrm{Uf}$, and $\mathrm{Mn}^{\mathrm{II}} \mathrm{Fe}^{\mathrm{III}} \mathrm{Uf}$ are considered. Stopped-flow first-order rate constants $k_{\text {obs }}$ (Table 3S, Supporting Information) are dependent on $\mathrm{pH}$ in the range 3.06.2, Figure 7. A single $\mathrm{p} K_{\mathrm{a}}$ effect is dominant, which is attributed to the deprotonation of the $\mathrm{Fe}^{\mathrm{III}}$ bound water. ${ }^{18}$

\section{Discussion}

In these studies five $\mathrm{M}^{\mathrm{II}} \mathrm{Fe}^{\mathrm{III}} \mathrm{Uf}$ substituted derivatives ( $\mathrm{M}^{\mathrm{II}}$ $=\mathrm{Mn}^{\mathrm{II}}, \mathrm{Co}^{\mathrm{II}}, \mathrm{Ni}^{\mathrm{II}}, \mathrm{Cu}^{\mathrm{II}}, \mathrm{Zn}^{\mathrm{II}}$ ) of pig $\mathrm{Fe}^{\mathrm{II}} \mathrm{Fe}^{\mathrm{III}} \mathrm{PAP}(\mathrm{Uf})$ have been prepared and characterized. As part of the characterization, details of the UV-vis absorbance peaks ( $\lambda$ and $\epsilon$ values) have been obtained, Table 1. Derivatives incorporating $\mathrm{Mn}^{\mathrm{II}}$ and $\mathrm{Ni}^{\mathrm{II}}$ have been studied for the first time. The $\mathrm{Mn}^{\mathrm{II}}$ and $\mathrm{Zn}^{\mathrm{II}}$ products are of particular interest because plant PAP forms with $\mathrm{Zn}^{\mathrm{II}} \mathrm{Fe}^{\mathrm{III}}$ and $\mathrm{Mn}^{\mathrm{II}} \mathrm{Fe}^{\mathrm{III}}$ active sites are known. ${ }^{7-9}$ Metal analyses indicate that all the derivatives have close to one $\mathrm{Fe}^{\mathrm{III}}$ and one $\mathrm{M}^{\mathrm{II}}$ per Uf molecule. An exception is with the $\mathrm{Cu}^{\mathrm{II}}$ derivative, where the initial product binds two $\mathrm{Cu}^{\mathrm{II}}$ atoms. The second $\mathrm{Cu}^{\mathrm{II}}$ does not greatly perturb the $\mathrm{Cu}^{\mathrm{II}}-$ $\mathrm{Fe}^{\mathrm{III}}$ reactivity and is selectively removed by treatment with edta. The tendency for two $\mathrm{Cu}^{\mathrm{II}}$ ions to become incorporated may be due to the increased affinity of $\mathrm{Cu}^{\mathrm{II}}$ for surface $\mathrm{N}$-donor groups.

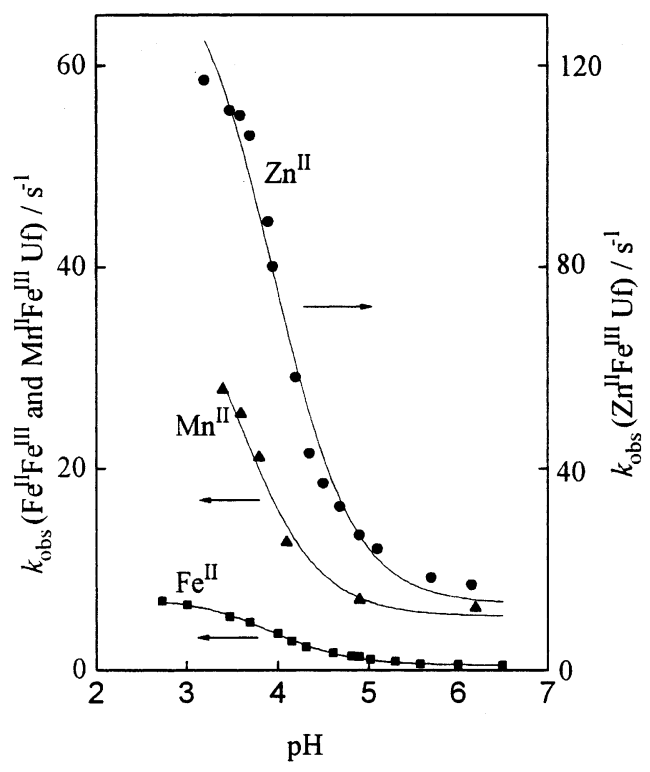

Figure 7. The variation of first-order rate constants $k_{\text {obs }}\left(25^{\circ} \mathrm{C}\right)$ with $\mathrm{pH}$ for the reaction of $\mathrm{H}_{2} \mathrm{PO}_{4}{ }^{-}$with native $\mathrm{Fe}^{\mathrm{II}} \mathrm{Fe}^{\mathrm{III}} \mathrm{Uf}(\boldsymbol{\square}), \mathrm{Mn}^{\mathrm{II}} \mathrm{Fe}^{\mathrm{III}} \mathrm{Uf}(\boldsymbol{\Delta})$, and $\mathrm{Zn}^{\mathrm{II}} \mathrm{Fe}{ }^{\mathrm{III}} \mathrm{Uf}(\mathbf{O})$; protein concentrations $(10-40 \mu \mathrm{M}),\left[\mathrm{H}_{2} \mathrm{PO}_{4}{ }^{-}\right](5-45$ $\mathrm{mM}), \mathrm{pH}=2.7-6.5, I=0.100 \mathrm{M}(\mathrm{NaCl})$.

In the case of kbPAP three histidines His-202, His-295, and His-296 have been identified close to the active site, flanking entry to the $\mathrm{Zn}^{\mathrm{II}} \mathrm{Fe}^{\mathrm{III}}{ }^{7}$ Of these, His-202 and His296 are conserved in the mammalian forms as His-92 and His-195, Figure 2. The X-ray structures of mammalian $\mathrm{Fe}^{\mathrm{III}}$ $\mathrm{Fe}^{\mathrm{III}}$ forms have indicated $\mathrm{H}$-bonding of these histidines to a bridging phosphate. ${ }^{13,14}$ The histidines are also able to provide an initial point of contact of $\mathrm{H}_{2} \mathrm{PO}_{4}{ }^{-}$and other phosphate reagents with the PAP prior to binding to the dinuclear $\mathrm{M}^{\mathrm{II}} \mathrm{Fe}^{\mathrm{III}}$ site. Binding of the second $\mathrm{Cu}^{\mathrm{II}}$ to the His92 and His-195 residues adjacent to the active site seems unlikely, since in kinetic studies with $\mathrm{H}_{2} \mathrm{PO}_{4}{ }^{-}$, rate constants for the product with a second $\mathrm{Cu}^{\mathrm{II}}$ attached are similar to those with only a single $\mathrm{Cu}^{\mathrm{II}}$ present.

The mechanism proposed previously for the reaction of $\mathrm{H}_{2} \mathrm{PO}_{4}{ }^{-}$with $\mathrm{Fe}^{\mathrm{II}} \mathrm{Fe}^{\mathrm{III}}$ Uf involves binding to the $\mathrm{Fe}^{\mathrm{II}}$ in a relatively rapid process, which does not contribute appreciably to UV-vis absorbance changes, followed by bridging to the more strongly chromophoric Fe ${ }^{\text {III }}{ }^{18}$ Such a reaction sequence is consistent with properties of high-spin $\mathrm{Fe}^{\mathrm{II}}$ and $\mathrm{Fe}^{\mathrm{III}}$ ions, the hexaaqua ions of which have waterexchange rate constants close to $10^{6} \mathrm{~s}^{-1}$ and $10^{3}-10^{4} \mathrm{~s}^{-1}$, respectively. ${ }^{27-29}$ The $\mathrm{M}^{\mathrm{II}}$ hexaaqua ions are also more labile than the $\mathrm{Fe}^{\mathrm{III}}$ ion. The reaction sequence eq $2-$ eq $3^{18}$ has been modified to account for the more complex rate dependence on $\left[\mathrm{H}_{2} \mathrm{PO}_{4}{ }^{-}\right]$, as illustrated in Figures 4 and 5. The experimental data were fitted to eq 10 , which is derived for the reaction sequence in Scheme 1 . Here, $K_{1}, K_{2}$, and $K_{\mathrm{i}}$ describe the equilibria for the binding of $\mathrm{H}_{2} \mathrm{PO}_{4}^{-}$, the formation of a $\mu$-phosphato bridge, and the binding of a second $\mathrm{H}_{2} \mathrm{PO}_{4}{ }^{-}$to the active site, respectively, the latter

(27) Lincoln, S. F.; Merbach, A. E. Adv. Inorg. Chem.; Academic Press: New York, 1995; Vol. 42, pp 2-88.

(28) Swaddle, T. W.; Merbach, A. E. Inorg. Chem. 1981, 20, 4212.

(29) See, for example: Wilkins, R. G. In Kinetics and Mechanism of Reactions of Transition Metal Complexes; VCH: Weinheim, 1991. 
giving the inhibition effect apparent in the inset to Figure 4.

Since $K_{2}$ describing the bridging process (Scheme 1) involves ligand substitution at the $\mathrm{Fe}^{\mathrm{III}}$ site, it is not expected to depend greatly on the identity of the divalent metal ion. Consistent with this, values obtained for the different $\mathrm{M}^{\mathrm{II}}$ identities lie within a factor of 1.6 (Table 3). Likewise $K_{\mathrm{i}}$ $\left(\sim 10^{3} \mathrm{M}^{-1}\right)$ for the binding of free $\mathrm{H}_{2} \mathrm{PO}_{4}{ }^{-}$to $\mathrm{Fe}^{\mathrm{III}}$ does not appear to vary appreciably with the identity of $\mathrm{M}^{\mathrm{II}}$. In contrast $K_{1}$ varies from 10 for $\mathrm{Ni}^{\mathrm{II}}$ to 60 for $\mathrm{Mn}^{\mathrm{II}}$, supporting a mechanism in which there is binding of $\mathrm{H}_{2} \mathrm{PO}_{4}^{-}$to the divalent metal ion.

As far as the formation constant $K_{1}$ is concerned, two stages, eqs 11 and 12 , seem likely. Prior association of

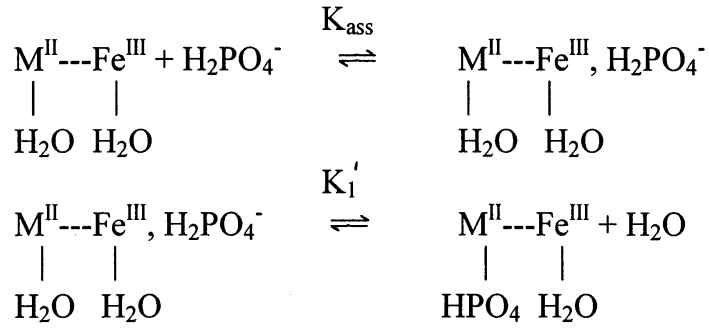

$\mathrm{H}_{2} \mathrm{PO}_{4}{ }^{-}$with the two histidine residues His-92 and His-195 is consistent with the mechanism proposed by Sträter et al. for kbPAP. ${ }^{4}$ The overall formation constant $K_{1}$ for $\mathrm{H}_{2} \mathrm{PO}_{4}{ }^{-}$ binding at the $\mathrm{M}^{\mathrm{II}}$ can therefore be modified to read $K_{\text {ass }} K_{1}{ }^{\prime}$. Studies on the oxidation of $\mathrm{Fe}^{\mathrm{II}} \mathrm{Fe}^{\mathrm{III}} \mathrm{Uf}$ with $\left[\mathrm{Fe}(\mathrm{CN})_{6}\right]^{3-}$ have provided evidence for a prior association. ${ }^{30}$ Thus the saturation kinetics observed are consistent with eqs 13 and 14,

$$
\begin{array}{ll}
\mathrm{Fe}^{\mathrm{II}} \mathrm{Fe}^{\mathrm{III}}+\left[\mathrm{Fe}(\mathrm{CN})_{6}\right]^{3-} \underset{\mathrm{Ke}}{\rightleftharpoons} \mathrm{Fe}^{\mathrm{II}} \mathrm{Fe}^{\mathrm{III}},\left[\mathrm{Fe}(\mathrm{CN})_{6}\right]^{3-} \\
\mathrm{Fe}^{\mathrm{II}} \mathrm{Fe}^{\mathrm{III}},\left[\mathrm{Fe}(\mathrm{CN})_{6}\right]^{3-} \stackrel{\mathrm{Ke}}{\rightarrow} & \mathrm{Fe}^{\mathrm{III}} \mathrm{Fe}^{\mathrm{III}}+\left[\mathrm{Fe}(\mathrm{CN})_{6}\right]^{4-}
\end{array}
$$

where $K_{\mathrm{Fe}}$ is in this case $K_{\text {ass }}$ for the association of $\left[\mathrm{Fe}(\mathrm{CN})_{6}\right]^{3-}$, and $k_{\mathrm{Fe}}$ is for electron transfer from $\mathrm{Fe}^{\mathrm{II}}$ to the $\left[\mathrm{Fe}(\mathrm{CN})_{6}\right]^{3-}$. At $25^{\circ} \mathrm{C}, \mathrm{pH} 5.0$, the kinetic treatment gives $K_{\mathrm{Fe}}=540 \mathrm{M}^{-1}, I=0.100 \mathrm{M}(\mathrm{NaCl})$. Competitive inhibition is observed with redox inactive $\left[\mathrm{Cr}(\mathrm{CN})_{6}\right]^{3-}$ and $\left[\mathrm{Mo}(\mathrm{CN})_{8}\right]^{4-}$, when association constants defined as in eq 13 give $K_{\mathrm{Cr}}=$ $550 \mathrm{M}^{-1}$ and $K_{\mathrm{Mo}}=1580 \mathrm{M}^{-1} \cdot{ }^{30}$ Smaller values of $K_{\text {ass }}$ are expected in the case of the $1-$ reactant $\mathrm{H}_{2} \mathrm{PO}_{4}{ }^{-}$.

Values of $K$ (Table 2) for the formation step, eq 5 , give an 8-fold spread for $\mathrm{M}^{\mathrm{II}}=\mathrm{Cu}^{\mathrm{II}}>\mathrm{Mn}^{\mathrm{II}}>\mathrm{Zn}^{\mathrm{II}}>\mathrm{Co}^{\mathrm{II}} \sim \mathrm{Fe}^{\mathrm{II}}$ $>\mathrm{Ni}^{\mathrm{II}}$. These values (Figure $8 \mathrm{a}$ ) are compared with those for $1: 1$ complexing of $\mathrm{M}^{\mathrm{II}}$ hexaaqua ions with $\mathrm{HPO}_{4}{ }^{2-}$ and $\left(\mathrm{CH}_{3} \mathrm{O}\right) \mathrm{PO}_{3}{ }^{2-}$ (Figure $\left.8 \mathrm{~b}\right) .{ }^{31-33}$ The similar trends are of interest with the anomalous position of $\mathrm{Cu}^{\mathrm{II}}$ as expected for the Irving-Williams series. Previous observations ${ }^{33,34}$ that phosphate does not follow strictly the Irving-Williams sequence appear to be confirmed by the present studies.

Surprisingly both the rate constants $k_{\mathrm{f}}$ and $k_{\mathrm{b}}$ (Table 3) give $\sim 10^{2}$ variations as $\mathrm{M}^{\mathrm{II}}$ is varied. In the case of $k_{\mathrm{b}}$ there

(30) Aquino, M. A. S.; Sykes, A. G. J. Chem. Soc., Dalton Trans. 1994, 683.

(31) Saha, A.; Saha, N.; Ji, L.-N.; Zhao, J.; Gregan, F.; Sajadi, S. A. A.; Song, B.; Sigel, H. J. Biol. Inorg. Chem. 1996, 1, 231.

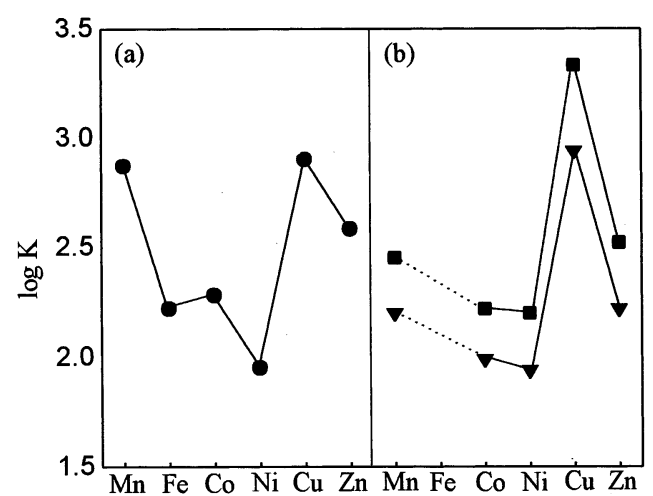

Figure 8. The variation of formation constants $K\left(25^{\circ} \mathrm{C}\right)$ with $\mathrm{M}^{\mathrm{II}}$ atomic number: (a) for $\mathrm{M}^{\mathrm{II}} \mathrm{Fe}^{\mathrm{III}}$ Uf derivatives with $\mathrm{H}_{2} \mathrm{PO}_{4}^{-}$() at $\mathrm{pH} 4.9$; and

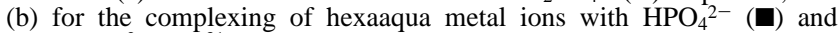
$(\mathrm{MeO}) \mathrm{PO}_{3}^{2-}(\boldsymbol{\nabla}) .31$

are two alternative mechanisms for the dissociation of the $\mu-\mathrm{PO}_{4}$ bridge, by cleavage of (i) $\mathrm{M}^{\mathrm{II}}-\mathrm{OPO}_{3}$ or (ii) $\mathrm{Fe}^{\mathrm{III}}-$ $\mathrm{OPO}_{3}$. The spread observed suggests that alternative (i) applies, since for a common $\mathrm{Fe}$ III- $\mathrm{OPO}_{3}$ cleavage values would be expected to be similar and independent of $\mathrm{M}^{\mathrm{II}}$. In the case of $k_{\mathrm{f}}$ for $\mathrm{HPO}_{4}{ }^{2-}$ bridging to $\mathrm{Fe}^{\mathrm{III}} \mathrm{a} \sim 10^{2}$ spread of values is not expected, suggesting that the fitting procedure is not sufficiently precise or that the mechanism proposed requires some further modification.

The $\mathrm{pH}$ dependences of $k_{\mathrm{obs}}$ for $\mathrm{M}^{\mathrm{II}} \mathrm{Fe}^{\mathrm{III}} \mathrm{Uf}\left(\mathrm{M}^{\mathrm{II}}=\mathrm{Fe}^{\mathrm{II}}\right.$, $\mathrm{Zn}$, $\mathrm{Mn}^{\mathrm{II}}$ ) with $\mathrm{H}_{2} \mathrm{PO}_{4}^{-}$are shown in Figure 7 . The downward trend with increasing $\mathrm{pH}$ is assigned to acid dissociation of the more acidic $\mathrm{Fe}^{\mathrm{III}}-\mathrm{H}_{2} \mathrm{O}$, eq 15 . Thus

$$
\mathrm{Fe}^{\mathrm{III}}-\mathrm{OH}_{2} \stackrel{\mathrm{K}_{1 \mathrm{a}}}{\rightleftharpoons} \mathrm{Fe}^{\mathrm{III}}-\mathrm{OH}+\mathrm{H}^{+}
$$

$\mathrm{p} K_{1 \mathrm{a}}$ is the main contribution to the trends observed, and from fits carried out values of 3.9, 3.9, and 3.6 respectively are obtained. Rate constants for bridge closure in eq 16

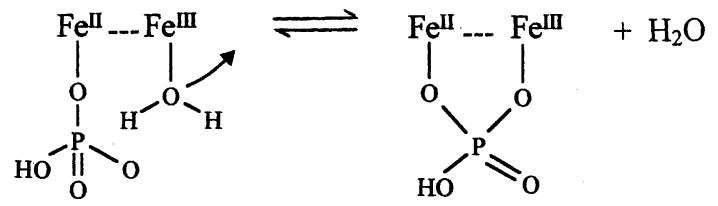

decrease at the higher $\mathrm{pH}$ 's as $\mathrm{Fe}^{\mathrm{III}}-\mathrm{OH}_{2}$ is replaced by $\mathrm{Fe}^{\mathrm{III}}-\mathrm{OH}^{-}$, because anionic phosphate does not as readily displace $\mathrm{OH}^{-}$as $\mathrm{H}_{2} \mathrm{O}$. In the case of the phosphate ester $\mathrm{ROPO}_{3}{ }^{2-}$, eq 17 , the displacement of $\mathrm{OR}^{-}$on the $\mathrm{P}^{\mathrm{V}}$ by the $\mathrm{OH}^{-}$results in ester hydrolysis. The activity of this process peaks at $\mathrm{pH} \sim 4.9$ when maximum $\mathrm{Fe}^{\mathrm{III}}-\mathrm{OH}^{-}$is present.

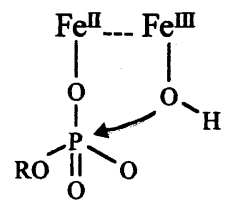

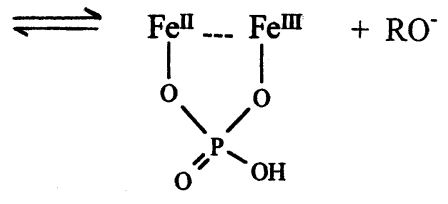

(32) Sigel, H.; McCormick, D. B. Acc. Chem. Res. 1970, 3, 201-208.

(33) Sigel, H.; Song, B. Met. Ions Biol. Syst. 1996, 32, 135-205.

(34) Shriver, D. F.; Atkins, P. W. In Inorganic Chemistry, 3rd ed.; Oxford University Press: Oxford, 1990; p 244. 
To summarize, in these studies the $\mathrm{Fe}^{\mathrm{II}}$ of $\mathrm{Fe}^{\mathrm{II}} \mathrm{Fe}^{\mathrm{III}} \mathrm{Uf}$ has been replaced in turn by $\mathrm{Mn}^{\mathrm{II}}, \mathrm{Co}^{\mathrm{II}}, \mathrm{Ni}^{\mathrm{II}}, \mathrm{Cu}^{\mathrm{II}}$, and $\mathrm{Zn}^{\mathrm{II}}$ and the products characterized. The use of $\mathrm{H}_{2} \mathrm{PO}_{4}{ }^{-}$as a substrate helps define steps relevant to the ester hydrolysis of $\mathrm{ROPO}_{3}{ }^{-}$. Various parameters have been determined including $K$ ( $=K_{1} K_{2}$ ) for the formation of the $\mu$-phosphate $\mathrm{M}^{\mathrm{II}} \mathrm{Fe}^{\mathrm{III}} \mathrm{Uf}$ products. The dependence of rate constants $k_{\mathrm{obs}}$ for the equilibration of $\mathrm{M}^{\mathrm{II}} \mathrm{Fe}^{\mathrm{III}} \mathrm{Uf}$ with $\mathrm{H}_{2} \mathrm{PO}_{4}{ }^{-}$is more complex than previously indicated, and is accounted for by inclusion of an inhibition step involving a second $\mathrm{H}_{2} \mathrm{PO}_{4}^{-}$as shown in Scheme 1. From a fit to the rate law (eq 10), $K_{1}$ for substitution on $\mathrm{M}^{\mathrm{II}}\left(10-60 \mathrm{M}^{-1}\right), K_{2}\left(=k_{\mathrm{f}} / k_{\mathrm{b}}\right)$ for $\mu$-phosphate formation (7.8-12.4), and $K_{\mathrm{i}} \sim 10^{3} \mathrm{M}^{-1}$ are obtained, which can be rationalized in terms of an involvement of $\mathrm{M}^{\mathrm{II}}$ (variable) or $\mathrm{Fe}^{\mathrm{III}}$ (invariable). Values of $K_{1}$ for the $\mathrm{H}_{2} \mathrm{PO}_{4}{ }^{-}$ binding to $\mathrm{M}^{\mathrm{II}}$ very likely incorporate $K_{\text {ass }}$ for the prior association of $\mathrm{H}_{2} \mathrm{PO}_{4}^{-}$to His-92 and His-195. Trends observed in $k_{\mathrm{f}}$ are less well understood. The $\mathrm{pH}$ dependence of rate constants $k_{\mathrm{obs}}$ indicates that the replacement of $\mathrm{OH}^{-}$ of $\mathrm{Fe}^{\mathrm{III}}-\mathrm{OH}^{-}$by $\mathrm{M}^{\mathrm{II}}$-attached $\mathrm{HPO}_{4}{ }^{2-}$ to give the $\mu$-phos- phate product is not as rapid as when $\mathrm{Fe}^{\mathrm{III}}-\mathrm{OH}_{2}$ is present. In these studies an order of effectiveness $\mathrm{Fe}^{\mathrm{II}}<\mathrm{Zn}^{\mathrm{II}}<\mathrm{Mn}^{\mathrm{II}}$ is observed for $\mathrm{K}$, and $\mathrm{Fe}^{\mathrm{II}}<\mathrm{Mn}^{\mathrm{II}}<\mathrm{Zn}^{\mathrm{II}}$ for $k_{\mathrm{obs}}$, with $\mathrm{Fe}^{\mathrm{II}}$ showing the more controlled behavior.

Acknowledgment. We are grateful to the UK Engineering and Physical Sciences Research Council for financial support, and Wellcome Foundation for a Travel Grant (to G.S.). We thank Professor L. Que, Jr. (Minneapolis), for a sample of $\mathrm{Zn}^{\mathrm{II}} \mathrm{Fe}^{\mathrm{III}} \mathrm{Uf}$ at the commencement of this work, and Dr. B. Horrocks (Newcastle) for helpful discussion and access to electrochemical equipment. A.G.S. is grateful to City University, Hong Kong, for a position as Visiting Professor during 2001, and G.S. to the University of Queensland for leave of absence.

Supporting Information Available: Tables $1 \mathrm{~S}, 2 \mathrm{~S}$, and $3 \mathrm{~S}$ with listing of rate constants. This material is available free of charge via the Internet at http://pubs.acs.org.

IC020037F 